\title{
ADAT PEMBAGIAN WARISAN PADA MASYARAKAT SUKU BAJO DI DESA TERAPUNG KECAMATAN MAWASANGKA KABUPATEN BUTON TENGAH
}

\author{
Rayon Alimran, Salimin A, Arsidik Asuru \\ Jurusan Pendidikan Pancasila dan Kewarganegaraan \\ Fakultas Keguruan dan Ilmu Pendidikan \\ Universitas Halu Oleo \\ Email: rayonalimran@gmail.com, saliminafamery@gmail.com, \\ suruarsidik@gmail.com
}

\begin{abstract}
Abstrak: tujuan penelitian ini yaitu untuk mengetahui: 1) objek yang menjadi warisan yang tidak dapat dibagi dan warisan yang dapat dibagi, 2) bagaimana mekanisme pembagian warisan menurut aturan adat pada masyarakat suku Bajo di Desa Terapung Kecamatan Mawasangka Kabupaten Buton Tengah.

Jenis penelitian yang digunakan adalah jenis penelitian deskriptif dengan analisis kualitataif, Subjek penelitian ini berjumlah 5 orang yang terdiri dari 1 orang tokoh adat, 1 orang tokoh agama, kepala desa dan 3 orang masyarakat yang menjadi ahli waris. Tehnik pengumpulan data yaitu: observasi, wawancara dan dokumenter.

Kesimpulan adat pembagian warisan pada masyarakat suku Bajo di Desa Terapung Kecamatan Mawasangka Kabupaten Buton Tengah dalam penelitian ini adalah: 1) objek warisan yang tidak dapat dibagi adalah bendera ula-ula, gendang, gong, gecong, jabatan adat dan ilmu ghaib. Objek warisan yang dapat dibagi berupa tanah, hewan ternak, sebagian dasar penghidupan seperti perhiasan emas, perabotan rumah, alat perlengkapan memancing. 2) mekanisme pembagian waris yang berlaku menggunakan cara musyawarah, waktu pembagian warisan tidak ditentukan, warisan dibagikan ketika kedua orang tua meninggal dunia, terlebih dahulu dilakukan penyelesaian utang-utang pewaris, warisan antara laki-laki dan perempuan sama besarnya, anak angkat dan anak tiri mendapatkan warisan berdasarkan kesepakatan antara ahli waris.
\end{abstract}

Kata Kunci : Pembagian Warisan; Objek Warisan; Suku Bajo. 


\title{
CULTURAL HERITAGE DISTRIBUTION IN THE TRIBE BAJO COMMUNITY IN TERAPUNG VILLAGE, MAWASANGKA DISTRICT, CENTRAL BUTON REGENCY
}

\author{
Rayon Alimran, Salimin A, Arsidik Asuru \\ Civic Education Department \\ Faculty of Teacher and Training Education \\ Halu Oleo University \\ Email: rayonalimran@gmail.com, saliminafamery@gmail.com, \\ asuruarsidik@gmail.com
}

\begin{abstract}
The purpose of this study is to find out: 1) the object that becomes a heritage that cannot be shared and a heritage that can be shared 2) how is the heritage distribution mechanism according to customary rules in the Bajo tribe community in Terapung Village, Mawasangka District, Central Buton Regency.

This study used descriptive research with qualitative analysis. The subjects of this study were 5 people consisting of 1 traditional leader, 1 religious leader, the village head, and 3 communities of heirs. Data collection techniques, namely: observation, interviews, and documentaries.

The conclusions of the cultural heritage distribution among the Bajo tribe community in Terapung Village, Mawasangka District, Central Buton Regency in this study are: 1) the objects of heritage that cannot be divided are the ula-ula flag, drums, gongs, gecong, traditional positions, and unseen knowledge. The objects of heritage that can be divided in the form of land, livestock, and some basic livelihoods are gold jewelry, household furniture, fishing equipment. 2) The mechanism of heritage distribution applies by deliberation, the time for distribution of heritage is not determined. The heritage is distributed when both parents pass away: settlement of the heir's debts first, the heritage between male and female is the same, adopted and stepchildren get a heritage based on an agreement between the heirs.
\end{abstract}

Keywords: Distribution of Heritage; Object of Heritage; Bajo Tribe.

\section{PENDAHULUAN}

Norma hukum adat pembagian waris dalam setiap suku atau masyarakat adat sering berbeda-beda. Norma Hukum adat pembagian waris merupakan salah satu norma hukum adat yang masih tetap dipertahankan hingga kini dikarenakan hal tersebut sangat penting dalam hal melanjutkan perpindahan waris pada satu generasi ke generasi selanjutnya. Terkadang hal tersebut menimbulkan masalah dikemudian hari antara ahli waris yang satu dengan ahli waris yang lainnya. Selama pembagian warisan itu berjalan baik, rukun dan damai di antara para waris, maka tidak diperlukan adanya campur tangan dari orang luar keluarga bersangkutan. Campur tangan dan kesaksian tua-tua adat atau para pemuka masyarakat hanya diperlukan apabila ternyata jalannya musyawarah untuk mencapai mufakat menjadi seret dan tidak lancar. Misalnya dikarenakan adanya perbedaan pendapat apakah waris anak angkat tidak perlu diberi bagian warisan ataukah dipandang perlu karena jasa-jasa mereka terhadap pewaris ketika hidupnya.

Suku Bajo sebagai salah satu suku yang mendiami beberapa daerah pesisir yang ada di Sulawesi Tenggara juga memiliki adat pembagian warisan mulai dari 
pewaris, ahli waris, proses pewarisan serta harta peninggalan yang tidak dapat dibagi dan harta peninggalan yang dapat dibagi. Tentu akan menjadi sangat berbeda dengan adat pembagian warisan pada suku lain, dikarenakan karakteristik yang unik dari suku Bajo itu sendiri.

\section{Hukum Waris Adat}

Hadikusuma (2015) menyatakan bahwa "hukum waris adat itu mempunyai corak dan sifat-sifat tersendiri yang khas indonesia, yang berbeda dari hukum Islam maupun hukum barat, sebab perbedaannya terletak dari latar belakang alam fikiran bangsa Indonesia yang berfalsafah Pancasila dengan masyarakat yang Bhinneka Tunggal Ika".

Soepomo (Soekanto, 2016) tentang hukum waris adat menyatakan bahwa: "memuat peraturan-peraturan yang mengatur proses mengoperkan barang-barang harta benda dan barang-barang yang tidak berwujud benda (immaterial goerderen) dari suatu angkatan manusia (generatie) kepada turunannya. Proses ini telah mulai dalam waktu orang tua masih hidup. Proses tersebut tidak menjadi akuut oleh sebab orang tua meninggal dunia. Memang meninggalnya bapak atau ibu adalah suatu peristiwa yang penting bagi proses itu, akan tetapi sesungguhnya tidak mempengaruhi secara radikal proses penerusan dan pengoperan harta benda dan harta bukan benda tersebut.

Anshori (2002) tentang warisan dilihat dari aspek jenjangnya harta dalam perkawinan dapat digolongkan menjadi 3 (tiga) macam, yaitu: Harta kekayaan adalah seluruh harta yang dimiliki oleh seseorang secara pribadi dan atau secara bersama-sama ketika masih hidup. Harta peninggalan adalah seluruh harta benda yang ditinggalkan oleh orang yang meninggal dunia dan menjadi hak ahli waris. Adapun warisan merupakan harta sisa setelah diambil biaya perawatan, penguburan jenazah, pelunasan utang, dan penunaian wasiat. Pendapat lain mengatakan warisan adalah segala sesuatu milik pewaris yang dibagi-bagikan kepada ahli waris. Warisan ini dapat berupa harta benda yang berwujud dan tidak berwujud. Warisan berwujud benda misalnya sebidang tanah, bangunan, pakaian adat, peralatan rumah tangga, alat dapur dan lain-lain. Sedangkan warisan yang tidak berwujud diantaranya gelar adat, hutang-hutang, amanat atau perjanjian, ilmu gaib dan lain-lain.

Zainuddin (2008) tentang konsep pewaris menyatakan bahwa: "pewaris adalah orang yang telah meninggal dunia dan meninggalkan sesuatu yang dapat beralih kepada keluarga yang masih hidup, baik keluarga melalui hubungan kekerabatan, perkawinan maupun keluarga melalui persekutuan hidup dalam rumah tangga. Pengalihan harta kepada keluarga yang disebutkan terakhir ini, biasanya bersifat jaminan keluarga yang diberikan oleh ahli waris melalui pembagiannya. Oleh karena itu, tergolong sebagai pewaris adalah:

a) orang tua (ayah dan ibu)

b) saudara-saudara yang belum berkeluarga atau sudah berkeluarga tetapi tidak mempunyai keturunan

c) suami atau istri yang meninggal dunia".

Wicaksono (2011) tentang ahli waris menyatakan bahwa: "ahli waris menurut hukum waris adat dibedakan dalam tiga sistem kekeluargaan, yaitu patrilineal, matrilineal dan parental. Ahli waris dalam hukum waris adat yang 
sistem kekeluargaan patrilineal menentukan bahwa anak laki-laki yang menjadi ahli waris dari orang tuanya. Namun, anak laki-laki tidak dapat menentang jika orang tua memberikan sesuatu kepada anak perempuannya. Hukum waris adat dalam sistem kekeluargaan matrilineal menentukan bahwa anak-anak hanya dapat menjadi ahli waris dari ibu, baik harta pencaharian maupun harta bawaan (harta pusaka). Ahli waris dalam sistem kekeluargaan parental adalah anak laki-laki dan anak perempuan dengan hak yang sama atas warisan dari orang tuanya”.

\section{Pembagian Warisan Menurut Hukum Adat}

Wicaksono (2011) mengemukakan secara umum pembagiaan warisan menurut hukum adat yakni:

Pembagian warisan menurut hukum adat dilaksanakan menurut daerah masing-masing, yang berarti pula mempunyai adat masing-masing. Di Indonesia yang menjunjung tinggi musyawarah untuk mufakat, yang menetapkan pembagian warisan menurut musyawarah di antara para ahli waris dengan cara sebagai berikut.

a. Pembagian warisan dilaksanakan dalam waktu menurut adat kebiasaan masyarakat setempat, ada yang 40 hari setelah pewaris meninggal dunia ada pula 100 hari setelah pewaris meninggal dunia.

b. Selama anak-anak pewaris belum dewasa, harta warisan tidak akan dibagi.

c. Dilakukan musyawarah yang diwarnai rasa kekeluargaan, agar dalam membagi waris dapat menghasilkan pembagian yang adil bagi ahli waris.

d. Umumnya musyawarah dalam pembagian waris dihadiri sesama ahli waris, apabila diperlukan dengan disaksikan sesepuh desa/pamong desa.

e. Ada kalanya dalam pembagian waris tersebut diperlukan bantuan dari ulama untuk mengingatkan rasa keadilan dalam membagi waris serta telah terpenuhinya hukum agama yang dianutnya.

f. Apabila musyawarah tidak memenuhi kesepakatan, diselesaikan melalui pengadilan negeri.

g. Sebelum harta warisan dibagi ke masing-masing ahli waris, para ahli waris bertanggungjawab untuk melunasi utang dari pewaris setelah itu dibagi ke ahli waris.

h. Hibah yang telah dilakukan pewaris semasa hidupnya dapat dipakai untuk melunasi utang pewaris apabila harta warisan tidak cukup. Namun di beberapa adat tidak dapat dipakai untuk melunasi utang pewaris.

Wicaksono (2011) menjelaskan lebih lanjut tentang besaran bagian masingmasing ahli waris menurut hukum adat secara umum yaitu:

"Besaran bagian masing-masing ahli waris:

1. Anak kandung baik laki-laki maupun perempuan mendapatkan pembagian yang sama, tetapi ada kalanya berlaku prinsip sepikul segendong (yang artinya $2: 1$ ), bagian anak perempuan separuh dari bagian anak laki-laki.

2. Anak angkat mendapatkan harta warisan bersifat seleranya dari ahli waris yang lain atas harta warisan yang ada, dapat pula berlaku hanya berhak atas harta pencaharian orang tua angkatnya. Apabila anak angkat menerima wasiat atau hibah, ada adat tertentu menentukan tidak boleh lebih dari $1 / 2$ seluruh harta warisan. 
3. Anak tiri mendapatkan harta warisan bersifat serelanya dari ahli waris yang lain atas warisan orang tua tirinya, atau adakalanya hanya dapat mewarisi harta dari orang tua kandungnya saja.

4. Anak tidak sah hanya mewarisi dari ibu kandungnya saja. Dibeberapa adat menetapkan bahwa anak tidak sah, tidak mewarisi bersama-sama dengan anak sah, walaupun pada akhirnya ibu menikah dengan ayah biologisnya.

5. Janda/duda menerima bagian warisan sama besar dengan seorang anak, apabila tidak ada anak, warisan jatuh semua pada janda/duda, sedangkan harta pusaka kembali ke asal. Janda/duda berhak atas 1/2 harta pencaharian.

\section{Warisan yang Tidak Dapat Dibagi dan Warisan yang Dapat Dibagi}

Warisan yang tidak dapat dibagi bisa berupa benda pusaka atau benda yang memiliki keistimewaan atau memiliki alasan tertentu sehingga benda tersebut tidak dapat dibagi tetapi bisa diwariskan kepada orang tertentu atau menjadi milik bersama suku masyarakat tersebut, sedangkan warisan yang dapat dibagi pada dasarnya semua benda yang bisa diwariskan dan dibagi karena jumlahnya yang banyak atau sifatnya yang umum misalnya benda-benda untuk keperluan berkeluarga seperti tanah, hewan ternak atau benda lainnya.

Soekanto (1981) tentang warisan yang tidak dapat dibagi menyatakan bahwa "di beberapa daerah di Indonesia terdapat suatu adat, bahwa harta peninggalan yang turun-temurun diperoleh dari nenek moyang tak dapat di bagi; jadi ahli-ahli waris harus menerimanya secara utuh. Contoh-contoh misalnya di Minangkabau (harta pusaka, "familiegoederen"), di Hitu Ambon (dati, "famievermogen"). Tiap-tiap anak turut menjadi anggota ("deelgenoot") dalam kompleks famili yang mempunyai barang-barang keluarga alias harta pusaka itu. Jika kompleks famili yang mempunyai harta pusaka itu menjadi terlalu besar jumlahnya, hingga terjadi pemecahan famili yang masing-masing berdiri sendiri, harta pusaka dipecah menjadi dua. Ini disebut gadang-manyimpang (Minangkabau) dan masing-masing famili mempunyai harta pusaka sendiri yang juga tidak diperbolehkan dibagi antara anggota-anggota. Jika seseorang di Minangkabau mempunyai harta sendiri yang ia dapat pada masa hidupnya (harta peninggalan), harta ini, jika orang itu meninggal dunia, milik warisnya tetap tidak terbagi. Dengan cara begitu harta pencarian ini menjadi harta pusaka. Yang berhak atas harta peninggalan ini ialah kompleks-famili yang dipimpin oleh kepala-famili, mamaq kepala waris (Minangkabau) atau kepala dati (di Hitu)".

Hadikusuma (2015) mengenai warisan yang tidak dapat dibagi, ia mengemukakan bahwa :"disamping itu ada warisan yang memang tidak dapat dibagi-bagikan penguasaan atau pemilikannya dikarenakan sifat benda, keadaan dan kegunaannya tidak dapat dibagi, misalnya harta pusaka, alat perlengkapan adat, senjata, jimat, ilmu gaib, jabatan adat, gelar adat dan lain sebagainya yang harus dipegang oleh waris tertentu dan dimanfaatkan untuk kepentingan bersama".

Soekanto (1981) tentang warisan yang dapat dibagi, bahwa "Jika anakanak sudah dewasa, meniggalkan orang-tuanya untuk membentuk keluarga sendiri (mencar, Jawa; manjae, Batak), seringkali mereka diberi sebidang sawah, suatu pekarangan dengan rumah, beberapa ekor sapi, sebagian dasar penghidupannya. Pewarisan ini pada masa hidupnya orang tua ("toescheiding tijdens het leven", marisake, Jawa) diperhitungkan dalam membagi harta dikemudian hari jika bapak 
(ibu) meninggal dunia. Cara pemberian tanah itu bukan jual-transaksi melainkan suatu pengalihan dalam lingkungan keluarga. Pewaris tanah ini harus dilakukan dihadapan kepala desa supaya terang.

\section{Masyarakat Suku Bajo}

Orang Bajo atau masyarakat suku Bajo merupakan masyarakat yang awalnya hidup dengan berpindah dari satu daerah ke daerah lain tetapi tinggal di atas perahu dan hanya sekali-sekali berlabuh ke daratan baik untuk mengambil kayu atau melakukan transaksi kepada masyarakat lain yang tinggal di daratan dengan menukar atau menjual ikan dan hasil tangkapannya di laut. Tetapi sekarang jumlah orang Bajo yang masih tinggal diatas laut sudah mulai berkurang karena mereka sudah mulai menetap dan membuat rumah di tepi laut atau pantai.

Muharram (1983) menyatakan bahwa: "orang Bajo mempunyai budaya maritim dimana seluruh kehidupannya tergantung dari laut sebagai satu-satunya ladang pencahariannya turun temurun. Istilah Bajo di Sulawesi Tenggara adalah nama kelompok masyarakat yang bermukim dilaut dimana mereka bekerja sebagai nelayan turun-temurun. Kelompok sosial tersebut di Philipina Selatan disebut Bajau di Malaysia disebut sama, dan di Indonesia populer dengan sebutan Bajo. H.A Nimmo seorang peneliti dari California, yang pernah melakukan penelitian tentang orang-orang Bajo di Bajoe Provinsi Sulawesi Selatan, membuktikan bahwa adanya kesamaan bahasa suku laut di pulau Zulu, Philipina Selatan dan orangorang Bajo di Bajoe Dr. Abu Hamid dari Universitas Hasanuddin dalam penelitiannya pada suku Bajo di Sulawesi Selatan mengatakan bahwa orang-orang Bajo di Asia Tenggara dahulu berasal dari Funan (Melayu Tua), sebuah kerajaan maritim raksasa di pinggir lautan yang sekarang di kenang dengan Myanmar".

Minanti (1994) tentang orang Bajo menyatakan bahwa "masyarakat suku Bajo adalah masyarakat yang menggantungkan hidup pada laut dan saling berinteraksi dengan menjadikan perairan laut sebagai sumber dalam menyatukan mereka secara teritorial, adat istiadat, sosial dan ekonomi”.

Jaelani (1994) tentang budaya orang Bajo menyatakan bahwa "budaya yang mereka miliki diwarisi secara turun temurun, pola kehidupan masyarakat Suku Bajo umumnya masih mempertahankan pemukiman di atas laut dan mempunyai keterkaitan secara batin yang mempengaruhi keadaan mereka dalam melakukan pekerjaan sebagai nelayan".

\section{METODE PENELITIAN}

\section{Lokasi dan Waktu Penelitian}

Penelitian ini dilaksanakan di Desa Terapung Kecamatan Mawasangka Kabupaten Buton Tengah dengan tujuan untuk mengetahui adat pembagian warisan pada masyarakat Suku Bajo di Desa Terapung Kecamatan Mawasangka Kabupaten Buton Tengah. Waktu penelitian dilaksanakan pada bulan Agustus 2019.

\section{Jenis dan Pendekatan Penelitian}

1. Jenis penelitian

Penelitian ini menggunakan jenis penelitian deskriptif dengan analisis kualitatif. Disebut penelitian deskriptif karena penelitian ini memberikan gambaran dan informasi yang nyata mengenai objek warisan yang tidak dapat 
di bagi dan objek warisan yang dapat di bagi serta mekanisme pembagian waris menurut adat pada masyarakat suku Bajo di Desa Terapung, Kecamatan Mawasangka, Kabupaten Buton Tengah.

2. Pendekatan penelitian

Penelitian ini menggunakan pendekatan kualitatif dengan maksud mendeskripsikan fenomena yang ada di dalam lokasi penelitan dengan menggunakan data kualitatif yaitu memperoleh data kualitatif dalam bentuk uraian atau narasi tentang adat pembagian warisan menurut suku Bajo di Desa Terapung Kecamatan Mawasangka Kabupaten Buton Tengah yang kesemuanya tidak dapat di ukur dengan angka.

\section{Subjek Penelitian}

Subjek penelitian terdiri dari tokoh adat, tokoh masyarakat, kepala desa/ perangkat desa, dan 3 (tiga) anggota masyarakat yang merupakan ahli waris dari suku Bajo di Desa Terapung, Kecamatan Mawasangka Kabupaten Buton Tengah.

\section{Teknik Pengumpulan Data}

1. Obsevarsi

2. Wawancara

3. Dokumentasi

\section{Tehnik Analisis Data}

Teknik analisis data Data yang diperoleh dalam penelitian ini dianalisis secara kualitatif dengan tujuan data yang telah diperoleh, kemudian diuraikan dalam bentuk kalimat yang logis dan sistematis untuk menjawab rumusan masalah yang ada dalam penelitian ini.

\section{Cakupan variable yang diteliti}

1. Variabel yang terdiri dari objek warisan yang tidak dapat dibagi seperti bendera Ula-ula, keris dan benda pusaka lainnya dan variabel objek waris yang dapat dibagi seperti perahu, rumah, perhiasan emas, alat memancing, dan harta lainnya selain harta yang tidak dapat dibagi.

2. Variabel bagian objek waris untuk bagian masing-masing ahli waris menurut mekanisme aturan adat Bajo tentang pembagian warisan pada ahli waris untuk anak kandung, untuk istri/suami (janda/duda) dan untuk anak angkat.

\section{HASIL DAN PEMBAHASAN}

\section{Adat Pembagian Warisan Pada Masyarakat Suku Bajo (Studi di Desa Terapung Kecamatan Mawasangka Kabupaten Buton Tengah)}

\section{Objek Warisan Yang Tidak Dapat Dibagi Pada Masyarakat Suku Bajo}

1. Benda Pusaka

Benda pusaka tersebut adalah bendera suku Bajo atau disebut "bendera ula-ula" yang tidak dapat diwariskan kepada ahli waris tertentu karena merupakan benda milik bersama yang dijaga dan dirawat bersama-sama. Tetapi sekarang di Desa Terapung "bendera ula-ula" tersebut sudah tidak ada karena tidak dilestarikan kembali oleh masyarakat yang suku Bajo di Desa Terapung Kecamatan Mawasangka. 


\section{Alat Perlengkapan Adat}

Alat perlengkapan adat pada mayarakat suku Bajo di Desa Terapung Kecamatan Mawangka yaitu gong dan gendang dari bentuk dan kegunaan sama dengan gong dan gendang yang digunakan suku-suku yang ada di daerah lain dan itu tidak dapat diwariskan kepada ahli waris tertentu karena merupakan milik bersama masyarakat suku Bajo desa Terapung Kecamatan Mawasangka.

3. Senjata

Senjata di suku Bajo desa Terapung Kecamatan Mawasangka sering disebut gecong atau keris dan diwariskan kepada anak laki-laki yang dianggap mampu bertanggungjawab dan siap dengan senjata tersebut. Gecong atau keris tidak harus diwariskan kepada anak laki-laki pertama bisa saja anak laki-laki yang lain.

4. Ilmu Ghaib

Masyarakat suku Bajo mengenal adanya ilmu ghaib dan hanya beberapa orang saja yang dipercaya memilikinya salah satunya yaitu sandro atau dukun kampung dan tidak diwariskan ke semua anaknya. dukun atau sandro ini juga bertugas untuk pelaksanaan upacara adat dan terkadang untuk memimpin proses penyembuhan seseorang yang sedang sakit.

5. Jabatan Adat

Jabatan adat pada masyarakat suku Bajo di Desa Terapung Kecamatan Mawasangka dipilih oleh masyarakat dengan cara musyawarah yang dilakukan oleh beberapa tokoh adat, kepala desa, perangkat desa dan beberapa anggota masyarakat.

\section{Objek Warisan Yang Dapat Dibagi Pada Masyarakat Suku Bajo}

\section{Sebidang Tanah}

Tanah atau sebidang tanah dimiliki untuk kemudian digunakan membangun rumah, dijadikan lahan pertanian atau peternakan. Pada masyarakat suku Bajo di desa Terapung Kecamatan Mawasangka meskipun suku Bajo lekat dan identik dengan laut atau tinggal di atas laut, juga ada yang memiliki tanah. ada sebagian masyarakat suku Bajo di Desa Terapung Kecamatan Mawasangka yang punya tanah dikarenakan sudah menempati daratan dan ada juga yang tidak mempunyai tanah karena hanya membuat rumah di pinggir laut (dekat pantai) dan tidak mencari atau membeli tanah di daratan.

2. Hewan Ternak

Hewan ternak biasanya dipelihara bersama-sama ketika akan di wariskan maka hewan ternak itu dilihat ada berapa ekor jika sedikit maka hewan ternak tersebut dipelihara bersama dan menunggu hewan ternak beranakpinak sehingga anak-anaknya yang kemudian dapat dibagi oleh para ahli waris.

3. Sebagian Dasar Penghidupan

Barang-barang yang termasuk bagian dasar kehidupan misalnya emas, jika hanya sedikit maka diberikan kepada anak perempuan, jika ada jam tangan ayahnya maka diambil oleh anak laki-laki. Terkait ranjang, kasur, bantal, piring, gelas dan barang-barang sejenisnya diberikan ketika anak-anak akan berkeluarga. Sedangkan barang lainnya seperti kapal, bagang, alat pancing dan alat penangkapan ikan yang belum dibagikan ketika anak-anaknya kawin akan dirawat bersama kemudiam dibagi ketika kedua orang tua sudah meninggal. 


\section{Mekanisme Pembagian Warisan}

1. Waktu Pelaksanaan

Masyarakat suku Bajo di Desa Terapung Kecamatan Mawasangka tidak mengenal hari-hari tertentu setelah kematian orang tua untuk pembagian warisan warisan dibagikan jika kedua orang tua sudah meninggal, kemudian diselesaikan terlebih dahulu semua utang kedua orang tua, perbaikan kuburan, dan terakhir semua anak-anak atau ahli waris sudah berkumpul.

2. Warisan Anak yang Belum Dewasa

Bagian anak yang belum dewasa biasanya diberitahukan kepada anak pertama agar saat pembagian anak pertama bisa memberitahukan amanah bagian warisan yang sudah diberikan oleh orang tua mereka kepada adikadiknya. Untuk anak yang belum dewasa jika kedua orang tua sudah meninggal dan akan dilakukan pembagian warisan maka bagian warisannya akan dirawat atau disimpan oleh kakak atau keluarganya menunggu hingga anak tersebut dewasa dan mampu merawat harta warisannya sendiri baru kemudian diberikan.

3. Cara Pembagian Warisan

Warisan tidak dapat dibagikan sebelum kedua orang tua meninggal artinya jika masih ada satu orang tua maka warisan tersebut belum dibagikan kepada ahli waris dan masih di rawat bersama-sama. orang tua sebelum meninggal biasanya selalu memberi tahu anak pertama tentang warisan dan bagian-bagian warisan yang harus diserahkan kepada adik-adiknya dan anak pertama yang memimpin jalannya musyawarah pembagian warisan tersebut. untuk anak kedua atau anak ketiga (jika ada empat orang anak) biasanya hanya menunggu keputusan dari anak pertama dan anak terakhir untuk pembagian warisan dan mereka tidak akan berkeras untuk menyatakan pendapat bahwa dia berhak atas barang tertentu yang dia inginkan.

4. Adanya Kehadiran Perangkat Desa

Pertama ada yang berpendapat bahwa kehadiran perangkat adat, perangkat desa atau tokoh agama dalam pembagian warisan dibutuhkan untuk memberikan arahan agar tidak terjadi perselisihan antara para ahli waris saat pembagian warisan. Pendapat kedua, kehadiran perangkat adat, perangkat desa dan tokoh agama hanya sebagai saksi pembagian agar di kemudian hari tidak menjadi masalah. Ketiga berpendapat bahwa kehadiran perangkat adat dalam pembagian warisan belum dibutuhkan selama pembagian warisan berjalan baik atau bisa dijadikan sebatas saksi saja.

5. Terlebih Dahulu Dilakukan Penyelesaian Utang-utang Pewaris

Ada yang menyatakan bahwa jika kakak pertama memiliki harta berlebih maka sebaiknya dia yang melunasi utang-utang pewaris tersebut dan jika tidak memiliki harta yang berlebih, maka harus di jual sebagian warisan untuk melunaskan utang-utang tersebut. Untuk mengetahui ada atau tidak adanya utang-utang pewaris maka sesaat setelah dikuburkannya pewaris ada perwakilan keluarga yang menanyakan kepada masyarakat yang ikut mengantar pewaris di penguburan tentang siapa-siapa saja yang berhubungan utang dengan pewaris untuk memberi tahu keluarga pewaris atau ahli waris agar hutang tersebut dapat diselesaikan. 


\section{PENUTUP}

\section{Kesimpulan}

1. Objek yang menjadi warisan yang tidak dapat dibagi dan warisan yang dapat dibagi dalam adat waris suku Bajo di Desa Terapung Kecamatan Mawasangka Kabupaten Buton Tengah yaitu, objek warisan yang tidak dapat dibagi adalah bendera ula-ula, gendang, gong, gecong, jabatan adat dan ilmu ghaib. Sedangkan objek warisan yang dapat dibagi adalah tanah, hewan ternak, emas (perhiasan), perahu, bagang (rumah laut penangkapan ikan), dan sebagian dasar penghidupan seperti perabotan rumah, tempat tidur, dan baju.

2. Mekanisme pembagian waris menurut aturan adat pada masyarakat suku Bajo di Desa Terapung Kecamatan Mawasangka Kabupaten Buton Tengah adalah menggunakan cara musyawarah yang dipimpin oleh ahli waris anak pertama, kemudian waktu pembagiannya tidak ditentukan, warisan dapat dibagikan ketika kedua orang tua sudah meninggal dunia, Sebelum dilakukan pembagian warisan maka terlebih dahulu dilakukan penyelesaian utang-utang pewaris, bagian warisan antara anak laki-laki dan perempuan sama besarnya dan untuk anak angkat dan anak tiri tetap mendapatkan warisan tergantung kesepakatan antara para ahli waris.

\section{Saran}

1. Kiranya masyarakat Bajo khususnya di Desa Terapung Kecamatan Mawasangka dapat memahami kembali dan dapat melestarikan adat istiadat yang telah ada terkait objek warisan yang tidak dapat dibagi terutama pelestarian kembali "bendera ula-ula" dan objek warisan yang dapat di bagi serta bagaimana mekanisme pembagian warisan yang berlaku.

2. Bagi tokoh adat sekiranya dalam adat pembagian warisan pada masyarakat Bajo khususnya di Desa Terapung Kecamatan Mawasangka mengajarkan kepada generasi muda yang akan datang untuk tetap mempertahankan budaya leluhur adat Bajo yang telah dibudayakan oleh nenek moyang kita untuk sekiranya dapat dipertahankan kelestariannya terutama dalam adat pembagian warisan.

\section{DAFTAR PUSTAKA}

Anshori, Abdul Gafur. 2002. Hukum Kewarisan Islam di Indonesia: Eksistensi dan Adaptabilitas. Yogyakarta: Ekonesia Fakultas Ekonomi UII.

Hadikusuma, Hilman. 2015. Hukum Waris Adat. Bandung: Citra Aditya Bakti.

Jaelani Ahmad. 1994. Sistem Kepercayaan Masyarakat Suku Bajo. Ujung Pandang: Sinar Grafika.

Minanti. 1994. Perkampungan Bajo di Bajoe. Ujung Pandang: Laporan Penelitian PLPIIS.

Muharram, La Ode. 1994. Suku Bajo (Studi Tentang Interaksi Sosial Masyarakat Suku Bajo dengan Masyarakat Sekitarnya di Kabupaten Muna Sulawesi Tenggara). Kendari: Fisip Unhalu.

Soekanto, Soerjono. 1981. Meninjau Hukum Adat Indonesia Suatu Pengantar Untuk Mempelajari Hukum Adat. Jakarta: CV. Rajawali.

Wicaksono, F Satrio. 2011. Hukum Waris. Jakarta: Visimedia.

Zainuddin, Ali. 2008. Pelaksanaan Hukum Waris di Indonesia. Jakarta: Sinar Grafika. 